\title{
POPULATION FLUCTUATION OF CERTAIN PESTS AND THEIR ASSOCIATED PREDATOR INSECTS ON SUGAR BEET IN SHARKIA GOVERNORATE, EGYPT
}

\author{
SHERIEF, E. A. H. ${ }^{1}$, A. A. A. SAID ${ }^{2}$, F.A.H. SHAHEEN ${ }^{2}$ and H. A. M. FOUAD ${ }^{1}$
}

1. Plant Protection Research Institute, ARC, Dokki, Giza, Egypt

2. Pesticides Dept., Fac. of Agric., Mansoura Univ., Egypt

(Manuscript received 8 April 2011)

\begin{abstract}
The present study was conducted on the sugar beet insect pests, Cassida vittata, Pegomia mixta and Myzus persicae, their related natural enemies inhabiting sugar beet fields of Zagazig district in Sharkia Governorate, Egypt during two successive growing seasons (2008/2009 and 2009/2010). In the first season, two peaks of Cassida vittata larvae and adult represented by 587, 695 larvae/50 plants and 243, 240 adult/50 plants, respectively. While, in the second season, two peaks for larvae were recorded and represented by 664,2250 larvae/50 plants respectively. In case of adult stage, four peaks were recorded and represented by 64,216 , 420 and 616 adults/50 plants, respectively. The sugar beet fly Pegomia mixta started appear on the plants on the $1^{\text {st }}$ week of December with few numbers (129 eggs/50 plants). Two peaks of eggs were found on sugar beet plant of the two seasons. These peaks were recorded and represented by 537,446 eggs/50 plants, in the first season. In the second season, these peaks were recorded and represented by 558, 543 eggs/50 plants. As for larval instars, it was noticed that it had two peaks of 487,533 larvae/50 plants, in the first season and the number of larvae reached 736 and 697 larvae/ plant in the second season. One peak of Myzus persicae on sugar beet plant during the two seasons. This peak was recorded and represented by 2945 insects/50 plants and 3089 insects/50 plants, respectively. About natural enemies Coccinella undecimpunctata and Chrysoperla Carnea appeared in November, 2008/2009 and 2009/2010 but Paederus alfierii was observed during January in both seasons. The peaks of the studied predacious insects occurred in February, of the first season almost similar trend was obtained during the second season of study and represented by 270 , 522, 132, 159, 302 and 395 predacious, respectively.
\end{abstract}

Keywords: sugar beet, Cassida vittata, Pegomia mixta, Myzus persicae and predators.

\section{INTRODUCTION}

Sugar beet (Beta vulgaris L.) is one of the most important sugar crops in the world. It considered as an important source of feed for livestock and pectin production from the pulp of sugar beet (Fouad et al. 2011). Several numbers of insects attack this crop e.g. beet fly Pegomia mixta (Vill.), tortoise beetle Cassida vittata (Vill.) and the green beach aphid Myzus persicae (Sulzer) caused considerable damage in its 
yield (Bassyouny 1987, Shaheen 1992, shalaby 2001 and El-Zoghbey et al. 2003). The total loss caused by insects in sugar beet was $8.2 \%$ in 1954 and $12.4 \%$ in 1965 (Kolbe 1967) .

In Egypt (Guirguis 1985) found that tortoise beetle Cassida vittata was one of the most serious and abundant species causing damage in sugar beet plants. The beet fly $P$. mixta live within the leaf between the upper and lower surfaces, their feeding at first creates winding mines caused acute damage for sugar beet chlorophyll content (Shaheen 1992).

Muska (2007) indicated that the green peach aphid (Myzus persicae) cause damage by sucking (aspiration) and transmission of virus diseases.

Population density of the predatory insects inhabiting sugar beet fields such as, Chrysopa carnea (Steph.), Coccinella undecimpunctata, Paederus alfierii (Koch), Scymnus sp and Cydonia vicina isis were studied by many author (Mesbah 1991, Ali et al. 1993, El-Agamy et al. 1996, El-Khouly 1998, Shalaby 2001, El-Khouly 2006.

The average daily number of $C$. vittata larvae consumed by one $C$. carnea larvae varied according to the age of prey, being $122.9,6.08$ and 4.06 for the three larvae instars of C. vittata, respectively. Present study is to contribute towards a better knowledge of the following aspects:

1- Survey and population fluctuation of C. vittata, P. mixta and M. persicae infesting sugar beet plants and their associated predatory insects.

2- Effects of some climatic factors on the population densities of these insects and their predators.

\section{MATERIALS AND METHODS}

The present investigation was carried out to survey and study the seasonal abundance of some important common insect pests, Cassida vittata (Vill.), Pegomyia mixta (Vill.) and Myzus persicae (sulzer.) and which attacking sugar beet plants their associated predators. The experiments were conducted at Kafr El-hamam village, Zagazig district, Sharkia Governorate Egypt, during 2008/2009 and 2009/2010 seasons.

An area of about half feddan was sowed with sugar beet " Baraca" variety, during the Mid. of November. Sampling from the experimental started after the completion of the vegetative growth and was carefully examined weekly in the morning from December until June during the two seasons. All regular cultural practices were carried out and no chemical control was applied. Weekly random samples of 50 plants were taken from the four field borders and the center of the field and counts of the immature stages and adults of pests and their associated predator 
so the samples were took weekly and calculated monthly, also the weekly temperature and relative humidity had been calculated to find out the relation ship between the temperature, relative humidity and certain sugar beet pests and predators during the two successive seasons.

Costat software program (2004) was applied for statistically analysis of results.

\section{RESULTS AND DISCUSSION}

\section{Seasonal abundances of certain insect pests attacking sugar beet plants:}

The seasonal abundance of the insect pests infesting sugar beet plants (Baraca variety): the sugar beet beetle, Cassida vittata Vill, the sugar beet fly, Pegomyia mixta Vill and the Aphids, Myzus persicae sulzer, was investigated in two consecutive seasons 2008/2009 and 2009/2010.

\section{Sugar beet beetle, $C$. vittata:}

Data represented in Fig. (1) showed that sugar beet plants were free from infestation or any stages of the beetle during a period elapsed of whole December and January for the two seasons of study.

In the first season, two peaks of both larvae and adult stages were recorded in $4^{\text {th }}$ week of April and $3^{\text {rd }}$ week of June and represented by 587 and 695 larvae/50 plants. While, two peaks were found for adult $1^{\text {st }}$ week of May and $1^{\text {st }}$ week of June and represented by 243 and 240 adult/50 plants, respectively. In the second season, two peaks of both larvae and pupae were recorded in, $1^{\text {st }}$ week of March and at the end of April and represented by 664, 2250 larvae/50 plants respectively, for larvae. While, pupae was recorded on $1^{\text {st }}$ and $5^{\text {th }}$ weeks of April and represented by 205, 290 pupae/50 plants. In case of adult stage, four peaks were found in $2^{\text {nd }}$ week of February, $1^{\text {st }}$ and $5^{\text {th }}$ weeks of April and $3^{\text {rd }}$ week of June and represented by 64,216 , 420 and 616 adults/50 plants, respectively.

Our results agree with that obtained by El-Khouly (1998) mentioned that the adults of $C$. vittata appeared in sugar beet fields by late February with low numbers and increased to its maximum in April recording two peaks. Shalaby (2001) showed that the $C$. vittata reached maximum as a complex of larvae and adults during March and April. El-Khouly (2006) observed that the initial appearance of C. vittata survivors occurred in January 2005 and 2006 reached a peak in April in both 2005 and 2006. 

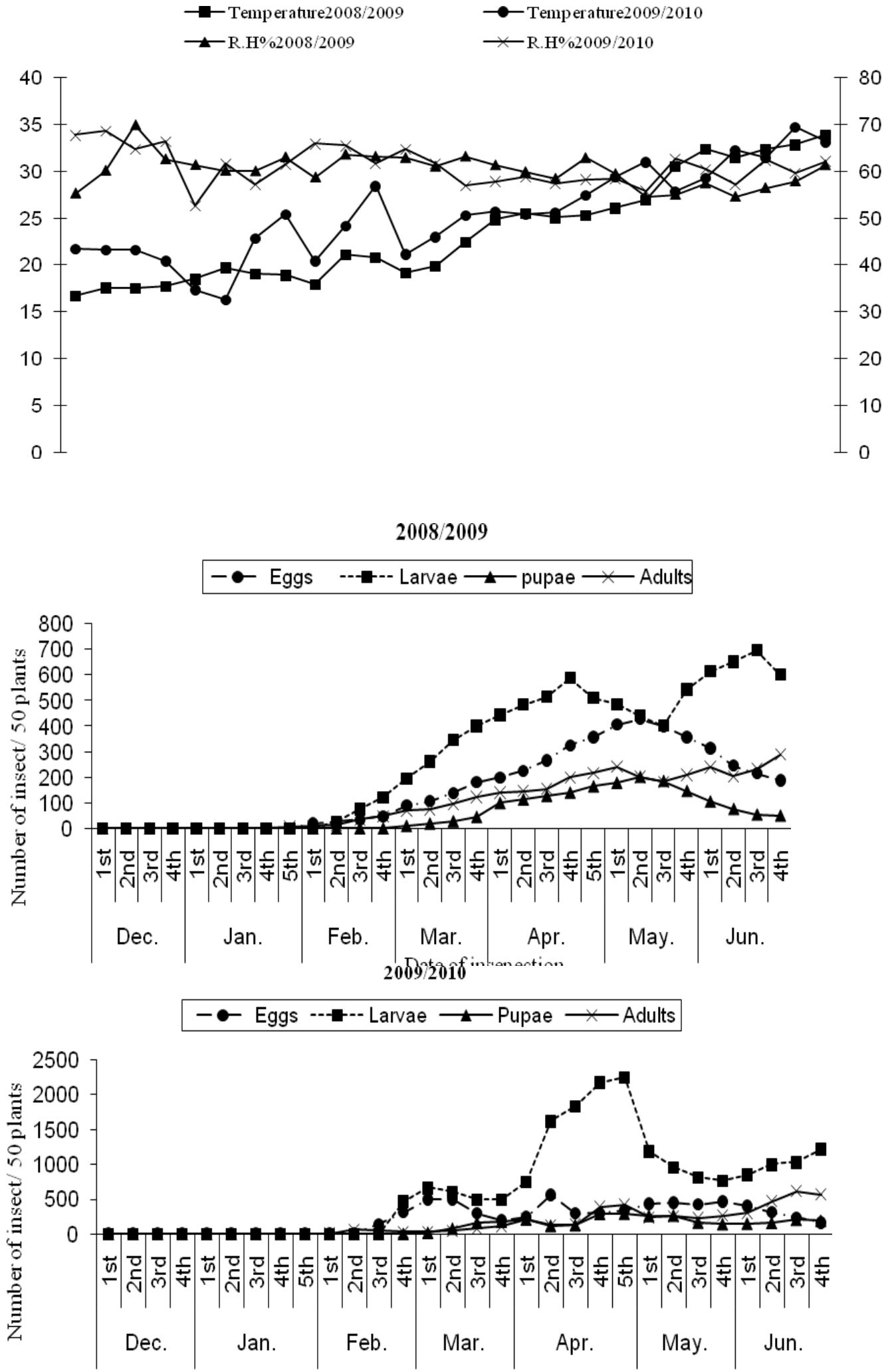

Date of inspection/week

Fig. 1. Population fluctuation of Cassida vittata infesting sugar beet plants in Sharkia Governorate during 2008/2009 and 2009/2010 seasons. 


\section{Sugar beet fly, P. mixta:}

Results in Fig. (2) illustrated that eggs began to appear in $1^{\text {st }}$ week of December with few numbers (129 eggs/50 plants). The number of the eggs had two peaks during the two seasons $2009 / 10$ and $2010 / 11$. These peaks were recorded in $3^{\text {rd }}$ week of March and 1st week of June, and represented by 537, 446 eggs/50 plants, respectively, in the first season. In the second season, these peaks were noticed in $2^{\text {nd }}$ week of February and $3^{\text {rd }}$ week of April and represented by 558, 543 eggs/50 plants, respectively. As for larval instars, it was noticed that it had two peaks of 487, 533 larvae/50 plants in $4^{\text {th }}$ week of March and $4^{\text {th }}$ week of May, respectively, in the first season. While, in the second season, three peaks of 736, 697 and 329 larvae/50 plants were recorded, in $4^{\text {th }}$ week of February, $4^{\text {th }}$ week of April and $2^{\text {nd }}$ week of May, respectively.

Our results agree with that obtained by Helal (2004) indicated that $P$. mixta population gradually increased until it reached its highest density in the March and April. In this respect, El-khouly (2006) found that the reliable occurrence of $P$. mixta individuals occurred in November was gradually increased forming distinct peak in March.

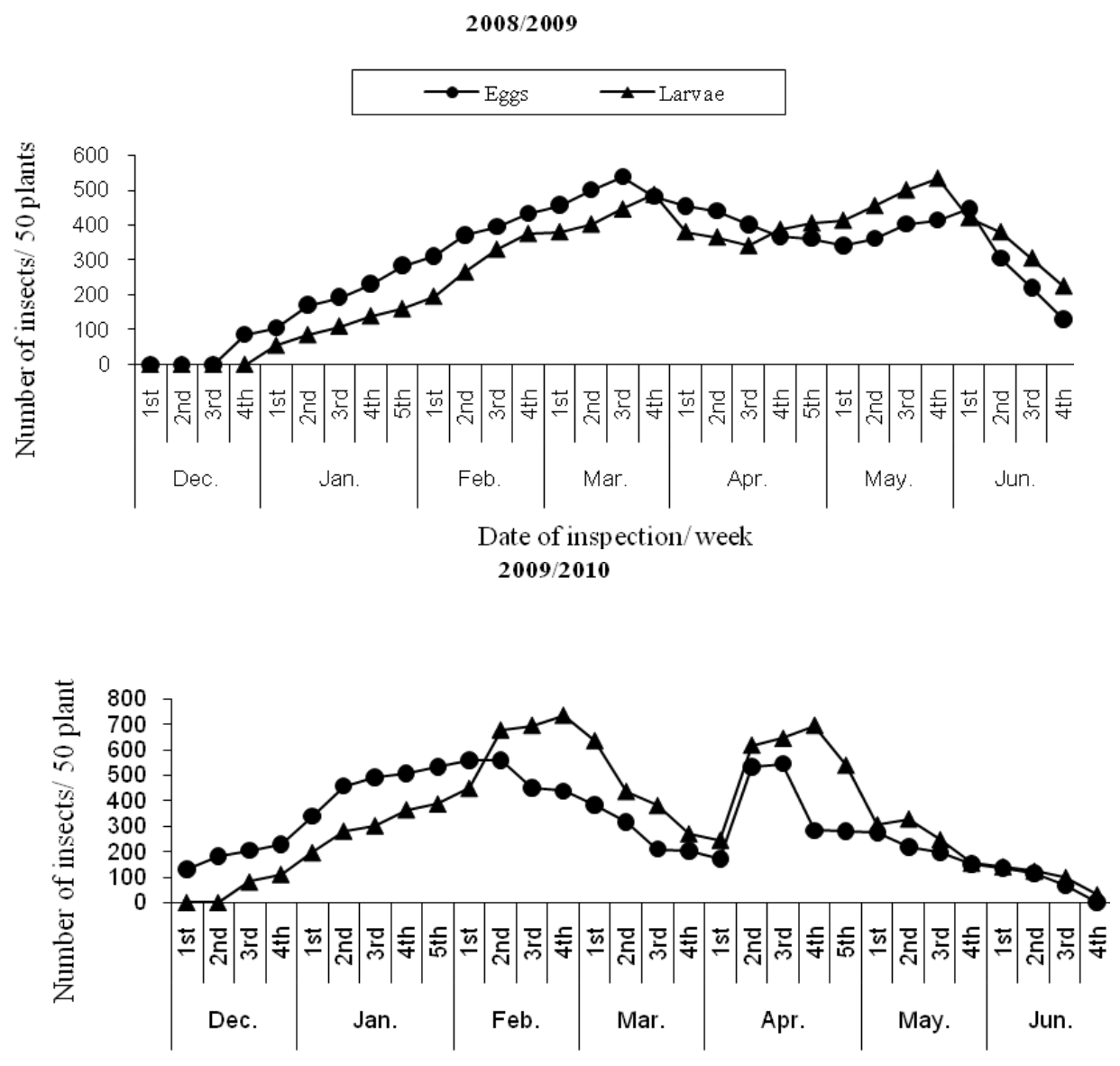

Date of inspection/ week

Fig. 2. Population fluctuation of Pegomyia mixta infesting sugar beet plants in Sharkia Governorate during 2008/2009 and 2009/2010 seasons. 


\section{Green beach aphid, Myzus persicae:}

Data presented in Fig. (3) revealed that Myzus persicae had one peak of abundance in the first season. This peak was recorded in $2^{\text {nd }}$ week of February and represented by 2945 insect/50 plants. While in the second season, also one peak of abundance was found in $3^{\text {rd }}$ week of February and represented by 3089 insect/50 plants.

Our results agree with that obtained by Ali et al. (1993) who mentioned that sever infestation of aphids were concentrated in October and November plantation. Talha (2001) found that the infestation with aphids was minimized at the late planting date.

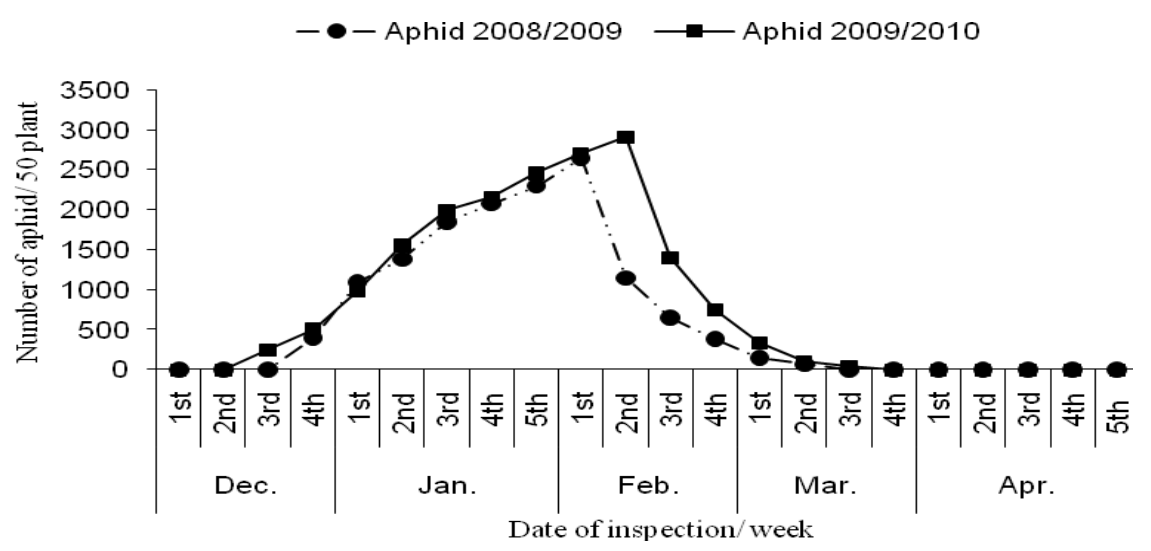

Fig. 3. Population fluctuation of Myzus persicae infesting sugar beet plants in Sharkia Governorate during 2008/2009 and 2009/2010 seasons.

Results in table (2) indicated that three injurious pests were recorded attacking sugar beet plants, these species are namely, C. vittata, P. mixta and M. persicae. The total numbers and ratio of these species were $C$. vittata (3230 individuals $=10.23 \%$ and 4786 individuals $=10.77 \%), P$. mixta $(8536$ individuals $=27.03 \%$ and 10186 individuals $=22.93 \%)$ and $M$. persicae $(19818$ individuals $=62.74 \%$ and 29460 individuals $=66.30 \%)$. 
Table 2. Total number of some injurious insect species and their percentages to the total catch on sugar beet during 2008/2009 and 2009/2010 seasons in Sharkia Governorate.

\begin{tabular}{|c|c|c|c|c|}
\hline \multirow{2}{*}{ Species } & \multicolumn{2}{|c|}{ Season (2008/2009) } & \multicolumn{2}{c|}{ Season (2009/2010) } \\
\cline { 2 - 5 } & $\begin{array}{c}\text { Number of } \\
\text { insects species }\end{array}$ & $\begin{array}{c}\text { \% of total } \\
\text { number }\end{array}$ & $\begin{array}{c}\text { Number of } \\
\text { insects species }\end{array}$ & $\%$ of total number \\
\hline Cassida vittata & 3230 & 10.23 & 4786 & 10.77 \\
\hline Pegomyia mixta & 8536 & 27.03 & 10186 & 22.93 \\
\hline Myzus persicae & 19818 & 62.74 & 29460 & 66.30 \\
\hline Total & 31584 & 100 & 44432 & 100.00 \\
\hline
\end{tabular}

\section{Population density of predacious insects:}

Concerning the predacious insects in fig. (4) indicated that the monthly numbers of $C$. undecimpunctata, $P$. alfierii and C. Carnea. The first and the $3^{\text {rd }}$ ones were appeared in November, while P. alfierii was observed in January, 2008/2009 and 2009/2010. The peaks of the studied predacious insects occurred in February, $2008 / 2009$ and 2009/2010 for first season. Almost similar trend was obtained during the second season of study and represented by 270, 522, 132, 159, 302 and 395 predacious, respectively.

Our results agree with that obtained by El-Khawalka et al. (1991) in Egypt found that the average daily number of $C$. vittata larvae consumed by one $C$. carnea larvae varied according to the age of prey, being $122.9,6.08$ and 4.06 for the three larvae instars of C. vittata, respectively. Youssef (1994) reported that three distinct peaks of P. alfierii, two peaks of coccinellid predators and two peaks of chrysopa carnea were recorded in September. Shalaby (2001) observed that the population density of coccinellids was high during March, April and may, after that he also found that population density of $C$. carnea was the highest in September plantation 

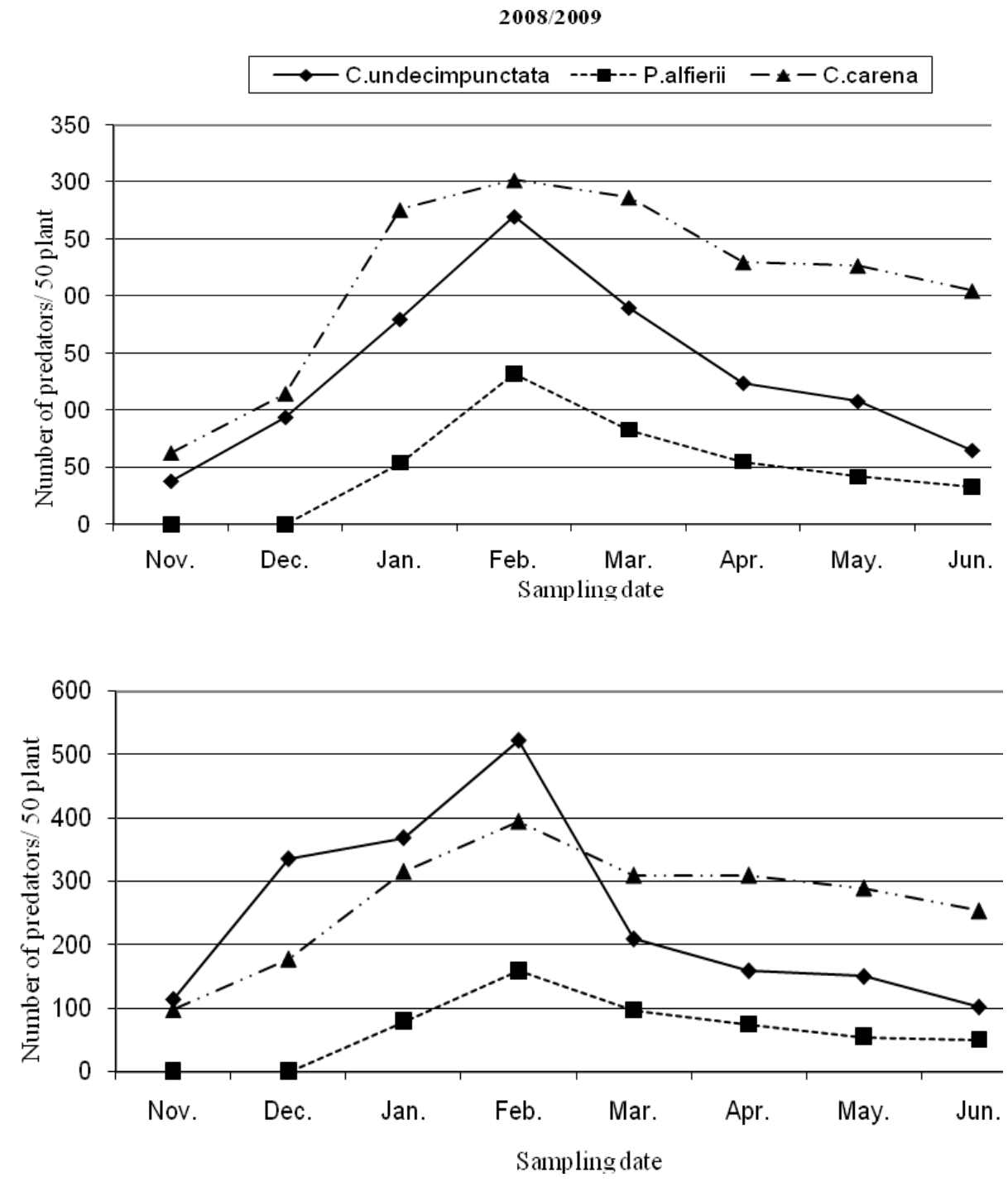

Fig. 4. Population fluctuation of associated predators in sugar beet fields in Sharkia Governorate during 2008/2009 and 2009/2010 seasons.

Results in table (3) showed predatory species found on sugar beet plants 2008/2009 and 2009/2010 seasons. Three beneficial insects, belonging to order: Coleoptera and Neuroptera. The mean numbers and ratio of these species were Coccinella undecimpunctata (136.14 individuals $=31.78 \%$ and 276.57 individuals $=$ 43.42\%), Paederus alfierii (57.71 individuals $=13.47 \%$ and 73.43 individuals $=$ $11.53 \%$ ) and Chersoperla carnea (234.57 individuals $=54.75 \%$ and 287 individuals $=$ $45.05 \%)$ in the two successive seasons, respectively. 
Table. 3. Mean number of predator's species and their percentages to the total catch on sugar beet crop during 2008/2009 and 2009/2010 seasons in Sharkia Governorate.

\begin{tabular}{|c|c|c|c|c|c|}
\hline & \multirow[b]{2}{*}{ Species } & \multicolumn{2}{|c|}{ Season $(2008 / 2009)$} & \multicolumn{2}{|c|}{ Season $(2009 / 2010)$} \\
\hline & & Number of & $\%$ of total & Number of & $\%$ of total \\
\hline \multirow{2}{*}{ Coleoptera } & C. undecimpunctata & 136.14 & 31.78 & 276.57 & 43.42 \\
\hline & P. alfierii & 57.71 & 13.47 & 73.43 & 11.53 \\
\hline Neuroptera & C. carnea & 234.57 & 54.75 & 287 & 45.05 \\
\hline \multicolumn{2}{|r|}{ Total } & 428.42 & 100.00 & 637.00 & 100.00 \\
\hline
\end{tabular}

Relation between temperature, relative humidity and certain sugar beet insects:

\section{Sugar beet beetle, $C$. vittata:}

The results obtained in Table (4) revealed that the correlation coefficient between total numbers of larvae and adult of $C$. vittata and maximum, minimum temperature was positive and high significant $\left(r_{1}=0.841 * *, 0871 * *\right),\left(r_{2}=0.838 * *\right.$, $\left.0.878^{* *}\right)$, in the first season respectively, and it was $\left(r_{1}=0.593^{* *}, 0.793^{* *}\right),\left(r_{2}=\right.$ $\left.0.583^{* *}, 0.872 * *\right)$ in the second season, respectively. Whereas, it was negative and high significant with minimum relative humidity $\left(r_{4}=-0.527 * *,-0.553 * *\right), \quad\left(r_{4}=\right.$ $-0.581 * *,-0.568 * *)$, respectively during the two seasons.

\section{Sugar beet fly, P. mixta:}

The correlation coefficient between larvae of $P$. mixta and maximum temperature, it was positive and high significant $\left(r 1=0.532^{* *}\right)$. While, minimum temperature it was positive and significant $\left(r 2=0.391^{*}\right)$ in the first season, respectively.

And about maximum and minimum relative humidity it was positively significant $\left(r 3=0.427^{*}\right)$, and high negatively significant $\left(r 4=-0.513^{* *}\right)$ in the first season, respectively.

\section{Green beach aphid, Myzus persicae:}

The correlation coefficient between $M$. persicae and maximum, minimum temperature, it was high negatively significant $\left(r 1=-0.506^{* *}\right),\left(r 2=-0.585^{* *}\right)$ in the first season, and also during the next season it was $\left(r 1=-0.587^{* *}\right),\left(r 2=-0.655^{* *}\right)$, respectively. 
Table. 4. Simple correlation coefficients between certain temperature components, relative humidity and total numbers of Cassida vittata, Pegomyia mixta and Myzus persicae on sugar beet plants in Sharkia Governorate during the period of 2008-2010.

\begin{tabular}{|c|c|c|c|c|c|c|c|c|c|}
\hline \multirow{3}{*}{ Insects } & \multirow{3}{*}{$\begin{array}{l}\text { Stages } \\
\text { of } \\
\text { growth }\end{array}$} & \multicolumn{8}{|c|}{ Simple correlation coefficients } \\
\hline & & \multicolumn{4}{|c|}{$2008 / 2009$} & \multicolumn{4}{|c|}{$2009 / 2010$} \\
\hline & & $\mathrm{r} 1$ & $\mathrm{r} 2$ & r3 & r4 & $\mathrm{r} 1$ & r2 & r3 & r4 \\
\hline \multirow[b]{2}{*}{ ర్ } & Larvae & $\begin{array}{c}0.841 * * \\
\pm 0.102\end{array}$ & $\begin{array}{c}0.838 * * \\
\pm 0.102\end{array}$ & $\begin{array}{c}0.298 \\
\pm 0.180\end{array}$ & $\begin{array}{c}- \\
0.527^{* *} \\
\pm 0.161\end{array}$ & $\begin{array}{c}0.593 * * \\
\pm 0.152\end{array}$ & $\begin{array}{c}0.583 * * \\
\pm 0.153\end{array}$ & $\begin{array}{c}0.207 \\
\pm 0.185\end{array}$ & $\begin{array}{c}- \\
0.581 * * \\
\pm 0.154\end{array}$ \\
\hline & adults & $\begin{array}{c}0.871 * * \\
\pm 0.092\end{array}$ & $\begin{array}{c}0.878 * * \\
\pm 0.090\end{array}$ & $\begin{array}{c}0.280 \\
\pm 0.181\end{array}$ & $\begin{array}{c}- \\
0.553 * * \\
\pm 0.157\end{array}$ & $\begin{array}{c}0.793 * * \\
\pm 0.115\end{array}$ & $\begin{array}{c}0.872 * * \\
\pm 0.092\end{array}$ & $\begin{array}{c}0.268 \\
\pm 0.182\end{array}$ & $\begin{array}{c}- \\
0.568^{* *} \\
\pm 0.156\end{array}$ \\
\hline $\begin{array}{c}\text { Pegomyia } \\
\text { mixta }\end{array}$ & Larvae & $\begin{array}{c}0.532^{* *} \\
\pm 0.160\end{array}$ & $\begin{array}{l}0.391^{*} \\
\pm 0.174\end{array}$ & $\begin{array}{l}0.427^{*} \\
\pm 0.171\end{array}$ & $\begin{array}{c}- \\
0.513^{* *} \\
\pm 0.162\end{array}$ & $\begin{array}{l}-0.130 \\
\pm 0.187\end{array}$ & $\begin{array}{l}-0.329 \\
\pm 0.178\end{array}$ & $\begin{array}{c}0.290 \\
\pm 0.180\end{array}$ & $\begin{array}{l}-0.227 \\
\pm 0.184\end{array}$ \\
\hline \multicolumn{2}{|c|}{ Myzus persicae } & $\begin{array}{c}- \\
0.506^{* *} \\
\pm 0.162\end{array}$ & $\begin{array}{c}- \\
0.585 * * \\
\pm 0.153\end{array}$ & $\begin{array}{l}-0.176 \\
\pm 0.186\end{array}$ & $\begin{array}{c}0.275 \\
\pm 0.181\end{array}$ & $\begin{array}{c}- \\
0.587^{* *} \\
\pm 0.153\end{array}$ & $\begin{array}{c}- \\
0.655^{* *} \\
\pm 0.143\end{array}$ & $\begin{array}{c}0.188 \\
\pm 0.185\end{array}$ & $\begin{array}{c}0.195 \\
\pm 0.185\end{array}$ \\
\hline \multicolumn{8}{|c|}{$\mathrm{r} 1=$ correlation coefficient between max. Temp. and number of insects } & & \\
\hline \multicolumn{8}{|c|}{$\mathrm{r} 2=$ correlation coefficient between min. Temp. and number of insects } & & \\
\hline \multicolumn{8}{|c|}{$\mathrm{r} 3=$ correlation coefficient between max. R.H. and number of insects } & & \\
\hline \multicolumn{8}{|c|}{$\mathrm{r} 4=$ correlation coefficient between $\min . \mathrm{R} . \mathrm{H}$. and number of insects } & & \\
\hline
\end{tabular}

\section{REFERENCES}

1. Ali, F. A., M. A. Samy, F. E. El-Adl and S. M. Ibrahim. 1993. Effect of planting dates on the infestation ration of the main insect in sugar-beet fields. J. Agric. Sci., Mansoura Univ., 18 (6): 1805- 1812.

2. Bassyouny, A.M. 1987. Studies on the insects of sugar beet in Kafr El- Sheikh Governorate. Ph D. Thesis, Fac. of Agric. Tanta. Univ.

3. Costat Statistical Software. 2004. Microcomputer program analysis version 4.20, Cohort Software, Berkeley, CA.

4. El-Agamy, F. M., S. M. I. Metwally, R. El-Sufty and A. Youssef. 1996. The relationship between population fluctuations of some important insect pests of sugar-beet and their insect predators at Kafr El-Sheikh Region. J. Agric. Res., Tanta Univ., 22(1): 69-76.

5. EL-Khawalka, M.H.M., M.A.E. Samy and K.A.A. Draz. 1991. Laboratory and field studied on the predacious efficiency of Chrysopa carnea (Stephens) when fed on different preys. J. Agric. Sci. Mansoura Univ. 16(2): 2998-3002. 
6. El-Khouly, M. I. I. 1998. Ecological studies and control of the tortoise beetle, Cassida vittata Villers in sugar beet ecosystem. Ph. D. Thesis, Fac. Agric, Al-Azhar Univ., 183 pp.

7. El-Khouly, M. I. I. 2006. Population Fluctuations of the Beet Fly, Pegomyia mixta Vill. and the Tortoise beetle. Cassida vittata (Vill) in Relation to Certain Associated Natural Enemies in Sugar Beet Fields at Kafr El-Sheikh Governorate, Egypt. E. j. bio. pest control, 16 (1), 25-28.

8. El-Zoghbey, A. A., F. A. Atalla and A. H. Mesbah. 2003. Effect of two biocides in controlling Cassida vittata (Vill.) and Spodoptera littoralis (Boisd.) infesting sugar beet plants. Ann. of Agric. Sci. Moshtohor. 41(1): 335-342.

9. Fouad, H. A. M., A. A. A. Said, F. A. H. Shaheen, E. A. H. Sherief. 2011. Control some pests infesting sugar beet in sharkia governorate. M. Sc. Thesis, Fac. Agric. Mansoura Univ., 121-122 pp.

10. Guirguis, G. Z. 1985. Studies on certain insects attacking sugar-beet in Western Desert, Egypt. Ph. D. Thesis, Fac. of Agric, Menoufiya Univ., 277 pp.

11. Helal, R. M. Y. 2004. Ecological studies on the main insect pests of sugar beet plants and the most common predators at Kafr El-Sheikh Region. J. Agric. Sci., Mansoura Univ., 29 (2): 911 -923.

12. Kolbe, W. 1967. Studies on mangold fly control (1957-1967), with reference to aphis control. Pflanzenschuts Nachr. Bayer 20, No. 4,644673.

13. Mesbah, A. H. 1991. Ecological and biological studies on parasites and predators of some insects at Kafr El-Sheikh Region. M. Sc. Thesis, Fac. Agric. Tanta Univ., 127 PP.

14. Muska, F. 2007. Damaging presence of aphids on sugar beet and beet in Czech Republic historical summary until 2005. Listy-Cukrovarnicke-a-Reparske., 123(9/10): 284-287.

15. Shaheen, F. A. H. 1992. Efficiency of field spray insecticides against some sugar beet pests, in Relation to their Effect on yield And sugar content. J. Agric. Sci. Mansoura. Univ. 17(11): 3642-3647.

16. Shalaby, G. A. M. 2001. Ecological studies on some important sugar beet pests and natural enemies and their control. Ph. D. Thesis, Fac. of Agric, Kafr El-Sheikh, Tanta Univ., 141 pp.

17. Talha, E. A. M. M. 2001. Integrated pest management of sugar-beet insects. M. Sc. Thesis, Fac. Agric, Mansoura Univ., 102 pp.

18. Youssef, A. E. 1994. Studies on certain insects attacking sugar beet. Ph. D. Thesis, Fac. of Agric, Kafr El-Sheikh, Tanta Univ., 134 pp. 
التذبذب العددى لبعض الآفات والمفترسات الحشرية التى تتواجد

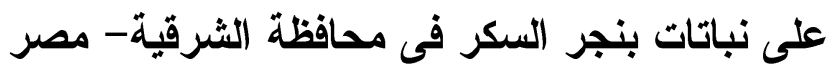

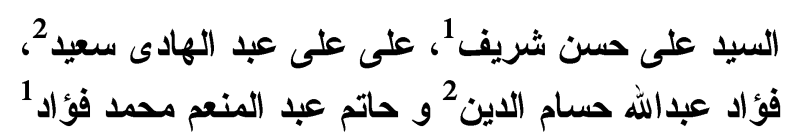

$$
\begin{aligned}
& \text { ا }
\end{aligned}
$$

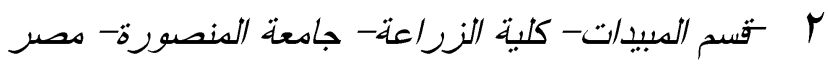

أجريت هذة الدر اسة لحصر بعض الآفات الحشرية مثل خنفساء البنجر السلحفائية ، ذبابة

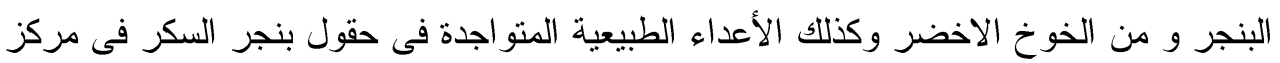

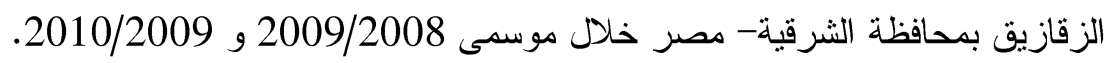

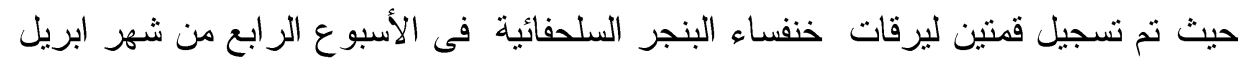

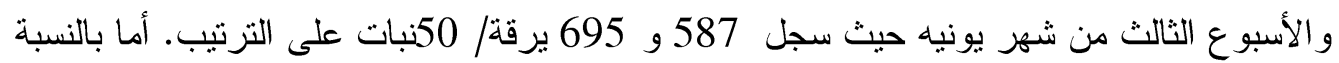

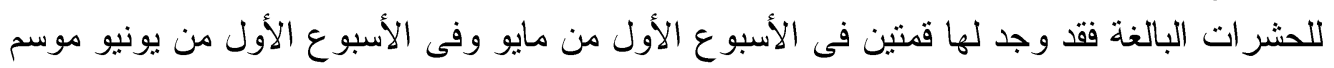

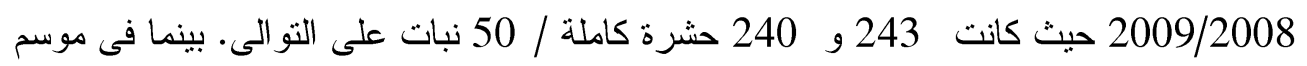

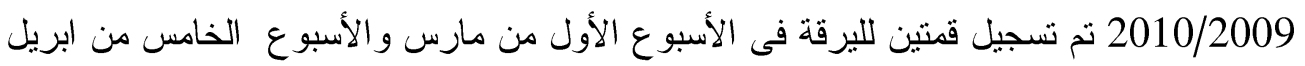

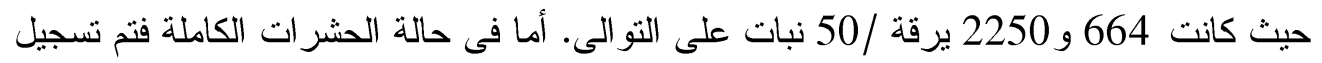

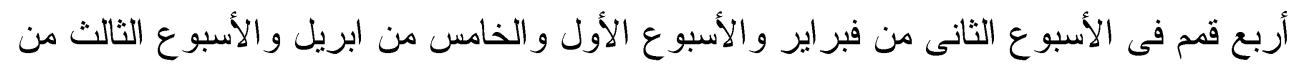
يونيه موسم 2009/2008حيث كانت على النو الى 64 64، 216، نبات، على النو الى. تون.

كما بدأت ذبابة البنجر فى الظهور على نباتات البنجر فى الأسبوع الأول من ديسمبر موسم

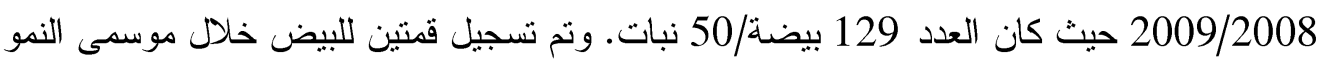

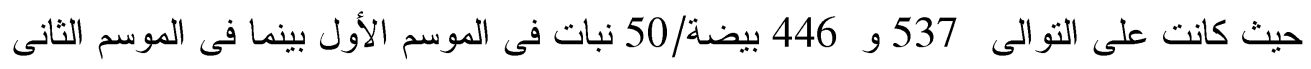

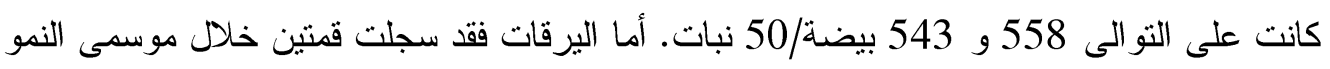

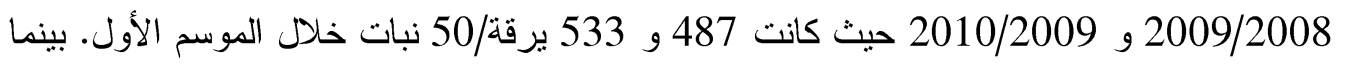

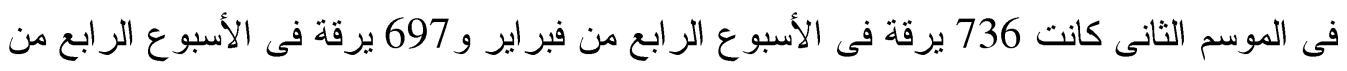

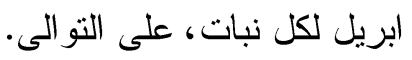
بينما سجلت قمة واحدة على نباتات البنجر خلال موسمى النمو حيث كانت فى الموسم الأول فى في

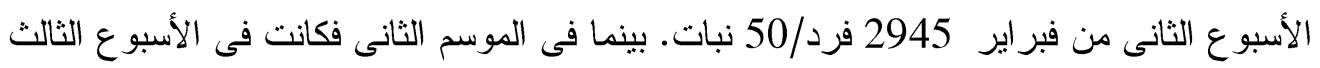
من فبر اير 3089 فرد/50 نبات. ايضا تم عمل حصر للأعداء الحيوية (أبو العيد، أسد المن و الحشرة الرواتشة). حيث ظهر كلا

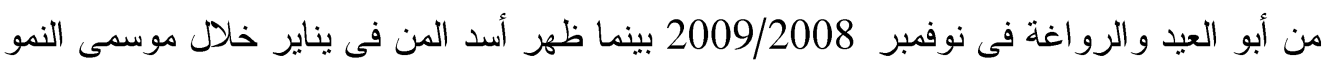

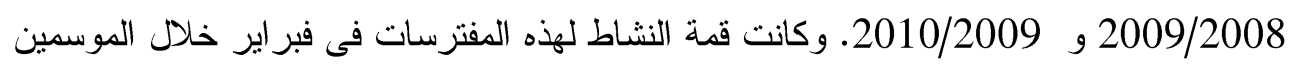

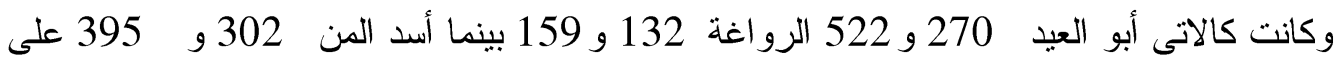

